\title{
Pellia endiviifolia (Dicks.) Dumort. Liverwort with a Potential for Water Purification
}

\author{
Agnieszka Parzych ${ }^{1} \cdot$ Jerzy Jonczak ${ }^{2} \cdot$ Zbigniew Sobisz $^{1}$
}

Received: 2 February 2018/Revised: 9 May 2018 / Accepted: 19 May 2018/Published online: 7 June 2018

(C) The Author(s) 2018

\begin{abstract}
The aim of this study was to assess accumulation ability of the liverwort of Pellia endiviifolia Dicks. Dum. in relation with macro- and trace elements uptake from stream water within the mid-forest headwater ecosystem. The research was carried out under conditions of limited impact of anthropogenic factors, which allowed assessing the nutrient needs and providing information on the accumulative possibilities of $P$. endiviifolia. The concentrations of 12 elements $(\mathrm{N}, \mathrm{P}, \mathrm{K}, \mathrm{Mg}, \mathrm{Ca}, \mathrm{Zn}$, $\mathrm{Fe}, \mathrm{Cu}, \mathrm{Ni}, \mathrm{Mn}, \mathrm{Al}$, and $\mathrm{Sr}$ ) in thalli of liverwort collected from three sites in northern Poland were determined by atomic absorption spectrometry and by microwave plasma atomic emission spectrometry. The thalli of the tested liverwort accumulated, on average, $2502.28 \mathrm{mmol}_{\mathrm{c}} / \mathrm{kg}$ of macro- and trace elements, with macronutrients accounting for $96.22 \%$ of this pool. Nitrogen constituted $40.3 \%$ of this sum, phosphorus $4.9 \%$, potassium $38.1 \%$, magnesium $5.0 \%$, calcium $12.1 \%$, and trace elements $3.78 \%$ of this sum. Among trace elements, the dominant share was represented by iron $56.30 \%$, manganese $24.80 \%$, and aluminum $16.95 \%$, and the share of other elements was lower than $1 \%$. Accumulation in thalli of $P$. endiviifolia high concentrations of iron and manganese confirms the potential use this species in the processes purification of waters contaminated with iron and manganese compounds. Based on the results of the research, it was found that the amount of accumulated $\mathrm{Mg}, \mathrm{Fe}$, and $\mathrm{Cu}$ was influenced by environmental conditions, whereas $\mathrm{N}, \mathrm{P}, \mathrm{K}, \mathrm{Ca}, \mathrm{Zn}, \mathrm{Ni}, \mathrm{Mn}$, $\mathrm{Al}$, and $\mathrm{Sr}$ rather by species-related features than environmental factors.
\end{abstract}

Keywords Stream $\cdot$ Water $\cdot$ Pellia endiviifolia $\cdot$ Accumulation $\cdot$ Macroelements $\cdot$ Trace elements

\section{Introduction}

Pellia endiviifolia (Dicks.) Dum. is a representative of thalloid liverworts of the Pelliidae subclass, the class of Jungermanniopsida (Crandall-Stotler and Stotler 2000; HeNygren et al. 2006). P. endiviifolia is a species widely distributed in the Northern Hemisphere, and it belongs to the hydrophilous liverworts. It occurs on stones, dead wood, most often in ditches, spring streams, and other damp places. It prefers limestone substrate (Osadowski

Agnieszka Parzych

parzycha1@op.pl

1 Institute of Biology and Environmental Protection, Pomeranian University in Słupsk, Arciszewskiego 22b, 76-200 Słupsk, Poland

2 Department of Soil Environment Sciences, Warsaw University of Life Sciences, Nowoursynowska 159, 02-776 Warsaw, Poland
2010). In the scientific literature, there is little information about the accumulative properties of this species. Little interest in liverworts is probably due to the difficulty in recognition of species. However, due to the occurrence of $P$. endiviifolia in both clean and polluted waters (Osadowski 2010) and its accumulative properties in relation with some impurities (Satake et al. 1987), this species may be useful in water treatment processes. Cleansing the environment with plants is a promising and future-proof alternative to conventional methods (Marecik et al. 2006; Siwek 2008; Grobelak et al. 2010; Astel et al. 2014; Parzych 2016). Phytoremediation is defined as the use of above-average abilities of some green plants to remove pollutants from the environment (Raskin et al. 1997). Plants used in the phytoremediation process are able to remove harmful substances from waters, soils, and bottom sediments (Hughes et al. 1997; Grobelak et al. 2010; Parzych 2016). Numerous plant species are highly efficient in removing of toxic substances as they have the ability to 
effectively take up or degrade harmful compounds (Parzych 2016; Parzych et al. 2015, 2016). Despite many studies carried out so far, phytoremediation is still at the stage of research and experiments, especially when it comes to the selection of appropriate plant species. Analysis of accumulative properties of $P$. endiviifolia in relation with macro- and trace elements occurring in the forest streams of headwater niches greatly enriches the area of knowledge on the accumulation possibilities and the use of this species in environmental protection.

The aim of the study was to evaluate the accumulation properties of $P$. endiviifolia in relation with $\mathrm{N}, \mathrm{P}, \mathrm{K}, \mathrm{Mg}$, $\mathrm{Ca}, \mathrm{Zn}, \mathrm{Fe}, \mathrm{Cu}, \mathrm{Ni}, \mathrm{Mn}, \mathrm{Al}$, and $\mathrm{Sr}$ taken from water and accumulated in the thalli within the forest headwater niches located far from anthropogenic pollution. The results of research carried out in conditions close to natural allow assessing the demand of a given species for nutrients and provide information on its accumulation properties.

\section{Materials and Methods}

\section{Research Area}

The research was carried out in headwater riparian forests located in the upper course of the Kamienna Creek $\left(54^{\circ} 19^{\prime} \mathrm{N} ; 17^{\circ} 10^{\prime} \mathrm{E}\right)$. It is an area of the Forest Inspectorate of Leśny Dwór in northern Poland (Fig. 1). Average annual sum of precipitation is about $770 \mathrm{~mm}$ and average annual temperatures about $7.6^{\circ} \mathrm{C}$ (Kirchenstein and Baranowski 2008).

The area of the Kamienna Creek catchment is nearly in whole covered by forests of a spatially diverse species composition with domination of beech, pine, and spruce in its plateau part, and common alder (Alnus glutinosa) in the valley bottom. The underground water flowing onto the surface form streams in which $P$. endiviifolia is found on the sandy bottom and stones. Soils in the vicinity of streams are rich in nitrogen, potassium, calcium, and magnesium, and relatively low in phosphorus (Jonczak et al. 2015). Plant and water samples were collected from three streams crossing peatbog under headwater riparian forest.

\section{Sampling and Analysis of Water}

Water samples were collected at monthly intervals in 2012-2014. Samples were collected using $0.5 \mathrm{dm}^{3}$ polyethylene bottles. Temperature, pH (CPI 551, Elmetron, Poland), and electrolytic conductivity (CC 315, Elmetron, Poland) were measured in the field. In the laboratory, concentrations of $\mathrm{K}^{+}, \mathrm{NH}_{4}^{+}, \mathrm{Mg}^{2+}, \mathrm{Ca}^{2+}, \mathrm{NO}_{3}^{-}$, and $\mathrm{PO}_{4}{ }^{3-}$ using ion chromatography were analyzed (881 Compact IC pro, Metrohm, Switzerland). Water samples were filtered through a $0.20 \mu \mathrm{m}$ sterile syringe filter and diluted with demineralised water. The accuracy of the output and QA/QC was based on certified reference material (Multi-element Ion Chromatography Anion Standard, Certified 89 866-50ML-F, Fluka, France). The concentration of $\mathrm{Fe}^{2 / 3+}, \mathrm{Mn}^{2+}, \mathrm{Zn}^{2+}, \mathrm{Cu}^{2+}$ and $\mathrm{Ni}^{2+}$ determined by atomic absorption spectrometry (AAS) (Aanalyst 300, Perkin Elmer, USA) and the concentration of $\mathrm{Al}$ and $\mathrm{Sr}$ by microwave plasma atomic emission spectrometry (Agilent 4100, MP-AES, Australia). The equipment was calibrated based on the original Merck standard solutions (KGaA, $1 \mathrm{~g} / 1000 \mathrm{ml})$. The obtained test
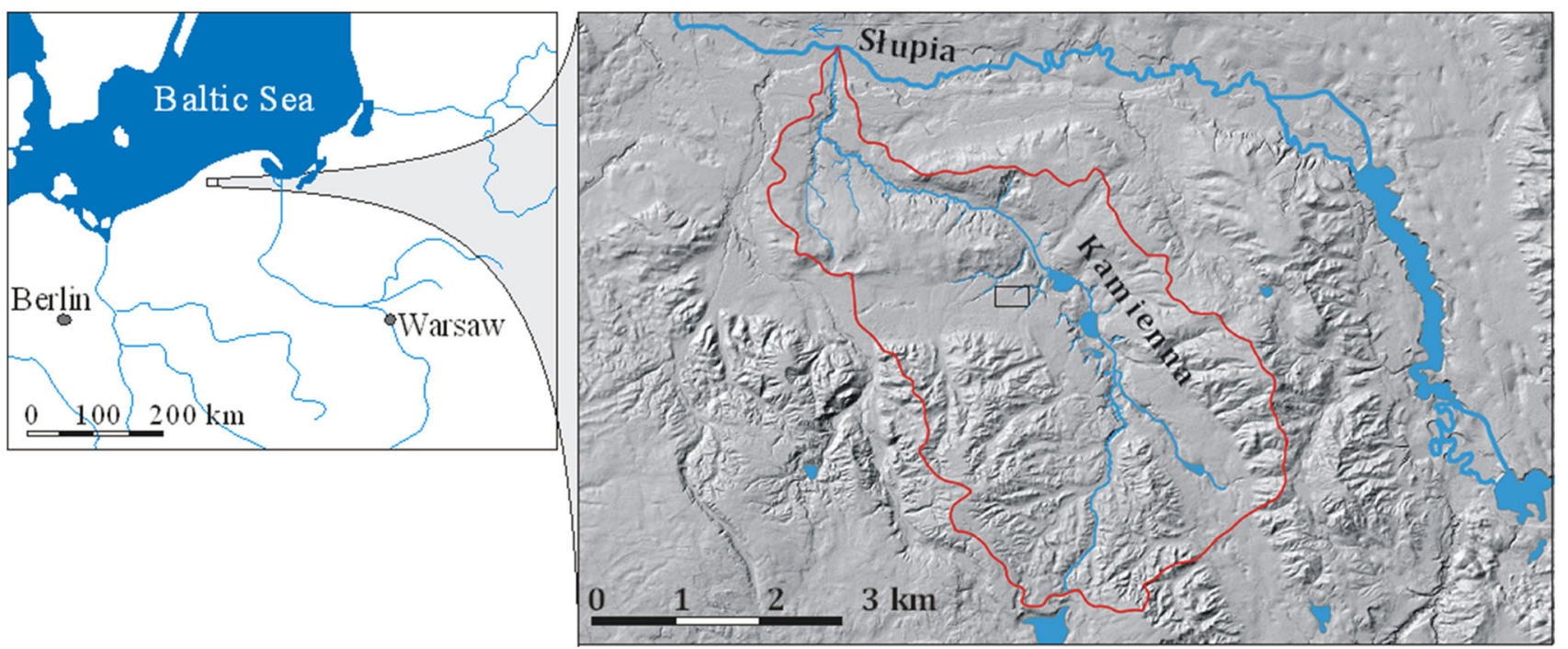

Fig. 1 Hydrographic network, the boundaries of the Kamienna Creek catchment and research area on the background of airborne LIDAR-based digital elevation model (DEM) 
results did not exceed the permissible error value of $\pm 3 \%$ in relation with the reference material.

\section{Sampling and Analysis of P. endiviifolia}

The liverwort samples were collected three times during the growing season-in May, July, and September, in the years 2012-2014. P. endiviifolia was collected from three streams by hand and washed several times in water at the sites. It was transferred into the laboratory polyethylene bags and washed carefully with deionized water in laboratory to remove attached inorganic and organic particles. Then, it was dried at $65^{\circ} \mathrm{C}$ and homogenized using laboratory grinder (IKA 11, Germany). The total nitrogen content was determined by Kjeldahl method (Büchi $350 \mathrm{~K}$, Switzerland) and phosphorus using the molybdate method (spectrophotometer UV-VIS U5100, Hitachi, Japan) after samples digestion in a mixture of $98 \% \mathrm{H}_{2} \mathrm{SO}_{4}$ and $30 \%$ $\mathrm{H}_{2} \mathrm{O}_{2}(1: 1 \mathrm{v} / \mathrm{v})$. For determination of metallic elements, plant samples were digested in a mixture of $65 \% \mathrm{HNO}_{3}$ and $30 \% \mathrm{H}_{2} \mathrm{O}_{2}(1: 1 \mathrm{v} / \mathrm{v})$. The concentration of $\mathrm{K}, \mathrm{Mg}, \mathrm{Ca}$, $\mathrm{Zn}, \mathrm{Fe}, \mathrm{Cu}, \mathrm{Ni}$, and $\mathrm{Mn}$ was determined by atomic absorption spectrometry (AAS) (Aanalyst 300, Perkin Elmer, USA), whereas $\mathrm{Al}$ and $\mathrm{Sr}$ with microwave plasma atomic emission spectrometry (Agilent 4100, MP-AES, Australia). The following wavelengths were used: $\mathrm{K}$ 769.9 nm, 202.6 Mg, 422.7 Ca, 213.9 Zn, 248.3 Fe, 324.8 $\mathrm{Cu}, 232.0 \mathrm{Ni}, 279.5 \mathrm{Mn}, 396.1 \mathrm{Al}$, and 407.8 Sr. The tests were carried out following the original standards of Merck $(\mathrm{KGaA}, 1 \mathrm{~g} / 1000 \mathrm{ml})$. The quality of the obtained results was controlled based on the analysis of certified samples of aquatic plants (CRM 060).

\section{Statistical Analysis}

The data composition was tested by the Shapiro-Wilk test. The physicochemical properties of waters and the chemical composition of $P$. endiviifolia in the tested stands were compared using Kruskal-Wallis test $(\mathrm{K}-\mathrm{W})$ at $p<0.05$. To identify the factors determining the content of macroand trace elements in thalli of $P$. endiviifolia, the factor analysis was applied (Principal Components Analysis, PCA). By means of the main components, two independent factors were separated, explaining $60 \%$ of the variability (variance) of $\mathrm{N}, \mathrm{P}, \mathrm{K}, \mathrm{Mg}, \mathrm{Ca}, \mathrm{Mn}, \mathrm{Fe}, \mathrm{Zn}, \mathrm{Cu}, \mathrm{Ni}, \mathrm{Sr}$, and $\mathrm{Al}$ concentrations in thalli of $P$. endiviifolia. The demand of $P$. endiviifolia for nutritional components was described by application of ANE method (Accumulation Nutrient Elements) (Ostrowska 1999). The sum of the macro- and trace elements calculated by the ANE method reflects in whole, co called, nutritional factor. The value of the sum of components and its ionic composition determine the circulation of the components between the water and the plant. The percentage participation of particular components in their sum is determined by alimentary requirements of $P$. endiviifolia in relation with particular components. The sum of components $(Y)$ in $\mathrm{mmol}_{\mathrm{c}} / \mathrm{kg}$ was calculated based on a formula:

$Y=\sum_{i=1}^{i}(Z: z)$

where $Z$ content of the element in $\mathrm{mg} / \mathrm{kg}, z$ atomic weight/ ion valency.

After the calculation of $Y$, the percentage $(X)$ of each element in the sum of

$X=[(Z: z) 100] Y^{-1}$,

was calculated. All calculations were performed using the software package Statistica 8.0 (Statsoft Inc., USA).

\section{Results}

\section{Physicochemical Properties of Water}

Waters of the studied streams were characterized by weakly alkaline reaction $(\mathrm{pH} 7.9-8.1)$ and the average electrolytic conductivity (EC), which ranged from 106.5 to $279.2 \mu \mathrm{S} / \mathrm{cm}$ (Table 1). The content of $\mathrm{K}^{+}$was from 0.98 to $1.11 \mathrm{mg} / \mathrm{dm}^{3}$ regardless of the location. $\mathrm{NH}_{4}{ }^{+}$ions were characterized by very low concentrations throughout the research period, taking average values from 0.05 to $0.08 \mathrm{mg} / \mathrm{dm}^{3}$. The predominant constituents of the stream water were $\mathrm{Ca}^{2+}$ ions, occurring in concentrations $56.5-61.2 \mathrm{mg} / \mathrm{dm}^{3} . \mathrm{Mg}^{2+}$ ions were present in much lower concentrations, on average from 1.83 to $2.65 \mathrm{mg} / \mathrm{dm}^{3}$.

The content of $\mathrm{NO}_{3}{ }^{-}$in stream waters ranged from 1.20 to $3.77 \mathrm{mg} / \mathrm{dm}^{3}$ depending on the stream, and the concentration of $\mathrm{PO}_{4}{ }^{3-}$ remained at the average level from 0.65 to $0.91 \mathrm{mg} / \mathrm{dm}^{3}$. The concentrations of $\mathrm{Fe}^{2 / 3+}$ and $\mathrm{Mn}^{2+}$ ions were on average from 0.23 to $1.45 \mathrm{mg} / \mathrm{dm}^{3}$ and from 0.07 to $0.29 \mathrm{mg} / \mathrm{dm}^{3}$, respectively. The remaining ions $\left(\mathrm{Zn}^{2+}, \mathrm{Cu}^{2+}, \mathrm{Ni}^{2+}, \mathrm{Sr}^{2+}\right.$, and $\left.\mathrm{Al}^{3+}\right)$ occurred in less than $0.01 \mathrm{mg} / \mathrm{dm}^{3}$. There were statistically significant differences demonstrated in the concentration of $\mathrm{NO}_{3}{ }^{-}, \mathrm{Fe}^{2 /}$ ${ }^{3+}, \mathrm{Mn}^{2+}$, and $\mathrm{EC}$ in the waters between the studied streams (Table 1).

\section{Concentration of Macro- and Trace Elements in $P$. endiviifolia}

The thalli of $P$. endiviifolia was characterized by varying chemical composition depending on the stream. Slight differences in the physicochemical properties of stream water (Table 1) influenced the amount of accumulated 
Table 1 Physicochemical properties of stream water from the studied mid-forest spring niches with Kruskal-Wallis's $(\mathrm{K}-\mathrm{W})$ test results

\begin{tabular}{lllll}
\hline Parameter & Location 1 & Location 2 & Location 3 & $\mathrm{~K}-\mathrm{W}, p<0.05$ \\
\hline $\mathrm{pH}$ & $7.9 \pm 0.1$ & $7.9 \pm 0.3$ & $8.1 \pm 0.4$ & - \\
$\mathrm{EC}, \mu \mathrm{S} / \mathrm{cm}$ & $279.2 \pm 55.5$ & $115.9 \pm 152$ & $106.5 \pm 143$ & $<0.01$ \\
$\mathrm{~K}^{+}, \mathrm{mg} / \mathrm{dm}^{3}$ & $1.11 \pm 0.7$ & $1.1 \pm 0.4$ & $0.98 \pm 0.3$ & - \\
$\mathrm{NH}_{4}{ }^{+}, \mathrm{mg} / \mathrm{dm}^{3}$ & $0.08 \pm 0.1$ & $0.07 \pm 0.1$ & $0.05 \pm 0.07$ & - \\
$\mathrm{Mg}^{2+}, \mathrm{mg} / \mathrm{dm}^{3}$ & $1.83 \pm 1.6$ & $2.65 \pm 1.7$ & $1.84 \pm 1.6$ & - \\
$\mathrm{Ca}^{2+}, \mathrm{mg} / \mathrm{dm}^{3}$ & $56.5 \pm 10.6$ & $61.2 \pm 10.4$ & $57.9 \pm 10.3$ & - \\
$\mathrm{NO}_{3}{ }^{-}, \mathrm{mg} / \mathrm{dm}^{3}$ & $3.77 \pm 1.9$ & $3.15 \pm 1.9$ & $1.20 \pm 1.7$ & $<0.001$ \\
$\mathrm{PO}_{4}{ }^{3-}, \mathrm{mg} / \mathrm{dm}^{3}$ & $0.65 \pm 1.1$ & $0.77 \pm 0.4$ & $0.91 \pm 0.8$ & - \\
$\mathrm{Fe}^{2 / 3+}, \mathrm{mg} / \mathrm{dm}^{3}$ & $0.23 \pm 0.01$ & $1.39 \pm 0.7$ & $1.45 \pm 0.5$ & $<0.01$ \\
$\mathrm{Mn}^{2+}, \mathrm{mg} / \mathrm{dm}^{3}$ & $0.07 \pm 0.001$ & $0.28 \pm 0.3$ & $0.29 \pm 0.4$ & $<0.01$ \\
$\mathrm{Zn}^{2+}, \mathrm{mg} / \mathrm{dm}^{3}$ & $<0.01$ & $<0.01$ & $<0.01$ & - \\
$\mathrm{Cu}^{2+}, \mathrm{mg} / \mathrm{dm}^{3}$ & $<0.01$ & $<0.01$ & $<0.01$ & - \\
$\mathrm{Ni}^{2+}, \mathrm{mg} / \mathrm{dm}^{3}$ & $<0.01$ & $<0.01$ & $<0.01$ & - \\
$\mathrm{Sr}^{2+}, \mathrm{mg} / \mathrm{dm}^{3}$ & $<0.01$ & $<0.01$ & $<0.01$ & - \\
$\mathrm{Al}^{3+}, \mathrm{mg} / \mathrm{dm}^{3}$ & $<0.01$ & $<0.01$ & $<0.01$ & - \\
\hline
\end{tabular}

macro- and trace elements in the liverworts. The average nitrogen content in $P$. endiviifolia was maintained at the level from 12,666 to $14,230 \mathrm{mg} / \mathrm{kg}$, phosphorus from 3447 to $3941 \mathrm{mg} / \mathrm{kg}$, potassium from 33,254 to $39,516 \mathrm{mg} / \mathrm{kg}$, magnesium from 2443 to $3382 \mathrm{mg} / \mathrm{kg}$, and calcium from 9792 to $12,708 \mathrm{mg} / \mathrm{kg}$ (Fig. 2). The average content of zinc was from 33 to $46 \mathrm{mg} / \mathrm{kg}$, iron from 1743 to $4019 \mathrm{mg} / \mathrm{kg}$, copper from 11 to $24 \mathrm{mg} / \mathrm{kg}$, nickel from 16 to $20 \mathrm{mg} / \mathrm{kg}$, manganese from 393 to $2866 \mathrm{mg} / \mathrm{kg}$, aluminum from 312 up to $518 \mathrm{mg} / \mathrm{kg}$, and strontium from 43 to $60 \mathrm{mg} / \mathrm{kg}$ (Fig. 2).

To identify the determinants of the chemical composition of the thalli of $P$. endiviifolia, principal component analysis (PCA) was used. In the calculations, the concentrations of $\mathrm{N}, \mathrm{P}, \mathrm{K}, \mathrm{Mg}, \mathrm{Ca}, \mathrm{Zn}, \mathrm{Fe}, \mathrm{Mn}, \mathrm{Cu}, \mathrm{Ni}, \mathrm{Sr}$, and $\mathrm{Al}$ in the thalli of liverworts in 2012-2014 were used (Table 2). By means of the principal components, two independent factors explaining 60\% variability (variance) of the chemical composition were distinguished. The values of factor loading, greater than 0.7 , were used to interpret the data. Factor 1 explained $39 \%$ of variance and grouped $\mathrm{P}, \mathrm{K}, \mathrm{Mg}$, and $\mathrm{Mn}$ characterized by very high positive factor loadings. Factor 2 explained $21 \%$ variability of chemical composition and was created by $\mathrm{N}$ and $\mathrm{Zn}$, characterized by high positive and negative factor loadings (Table 2), respectively.

\section{Accumulation of Macro- and Trace Elements in $P$. endiviifolia}

The thalli of the liverwort tested accumulated on average $2502.28 \mathrm{mmol}_{\mathrm{c}} / \mathrm{kg}$ of the analyzed components, with macronutrients accounting for $96.22 \%$ of this pool (Table 3).
The share of nitrogen accounted for $40.3 \%$ of this sum, phosphorus $4.9 \%$, potassium $38.1 \%$, magnesium $5.0 \%$, calcium $12.1 \%$, and trace elements accounted for $3.78 \%$ of the total amount. In total amount of micronutrients, iron had a dominant share with $56.30 \%$, manganese had $24.80 \%$ and manganese $16.95 \%$ (Table 3 ), while the remaining components accounted for less than $1 \%$.

\section{Discussion}

\section{Physicochemical Properties of Water}

Waters in the streams showed weakly alkaline reaction (Table 1), which is typical for young-glacial areas of northern Poland due to the prevalence of $\mathrm{CaCO}_{3}$ in the outflows of groundwater (Mazurek 2008; Parzych et al. 2016). Electrolytic conductivity of waters depends on the number of positive and negative ions, and its value in the case of the studied waters indicates for low mineralization (Parzych et al. 2018a, b). The studied streams flowed through the forest, which meant that an important role in modifying the chemistry of waters (Parzych et al. 2016) was played by organic matter falling down from the trees (Jonczak et al. 2016). The streams of water were regularly supplied with nutrients released from the decaying plant fall (Jonczak et al. 2016), which due to favourable conditions prevailing in the niches was almost completely decomposed during the first year (Jonczak et al. 2015). The concentration of calcium in stream waters was largely dependent on the carbonate balance (Bukowska-Jania 2003), and during growing seasons additionally on the vegetation demand for $\mathrm{Ca}^{2+}$ ions (Parzych et al. 2017, 2018a, b). The results of Osadowski's (2010) 

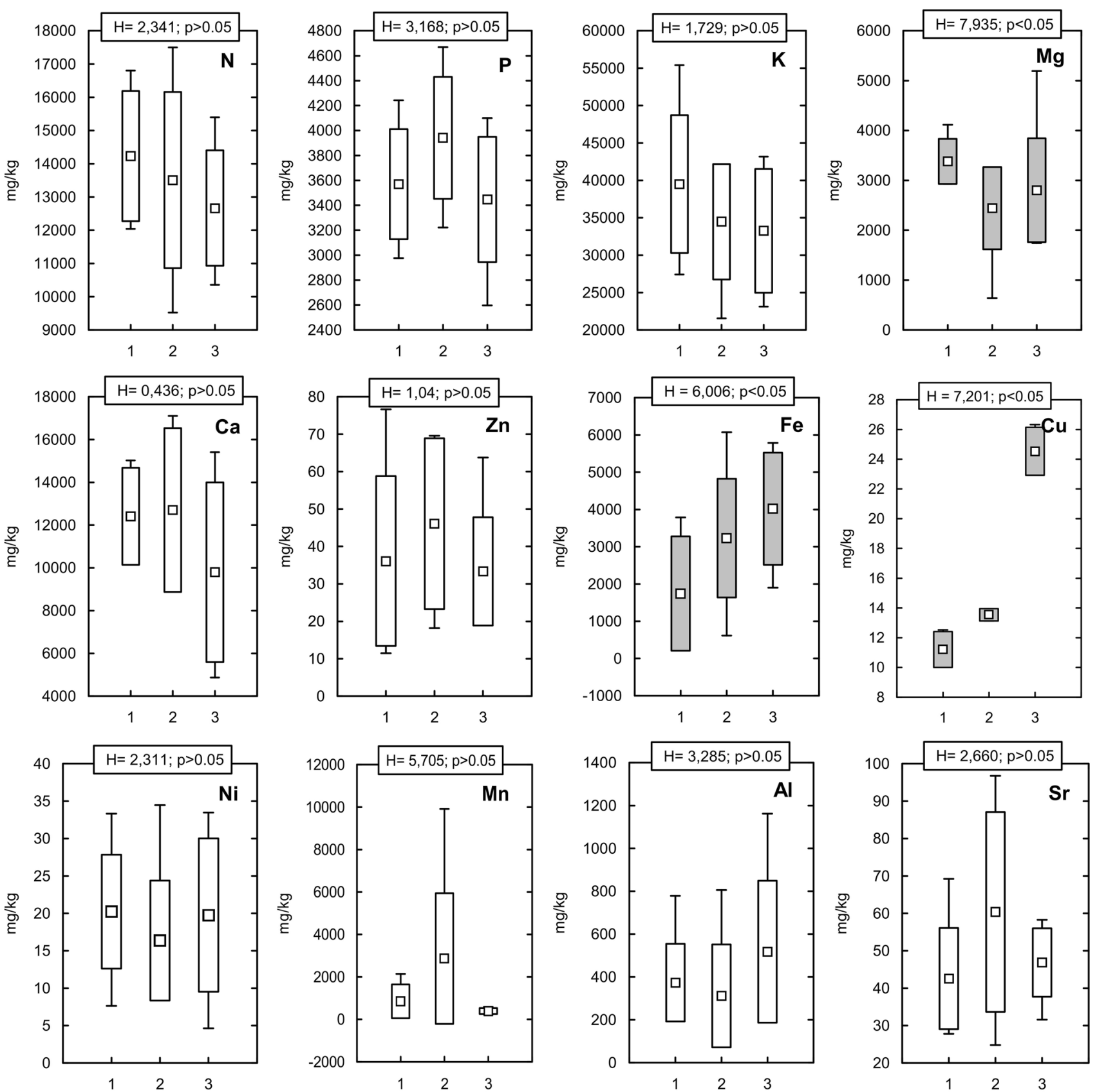

Fig. 2 Mean, minimum, maximum, and standard deviation of elements concentration in liverworts of Pellia endiviifolia in locations 1, 2, and 3 with Kruskal-Wallis test results. Colorless rectangles—no statistical significance, gray rectangles—statistically significant $(p<0.05)$

research indicate that the communities of $P$. endiviifolia are eager to occur in streams the waters of which are characterized by an increased content of $\mathrm{PO}_{4}{ }^{3-}$ ions. Although the soils in the vicinity of the streams contained a low phosphorus, their waters were fed with phosphorus compounds mainly from decomposition of organic matter (Jonczak et al. 2016), lying in the bottom of the streams. Both $\mathrm{PO}_{4}{ }^{3-}$ and $\mathrm{NO}_{3}{ }^{-}$ions during vegetation seasons are intensively absorbed by plants (Parzych et al. 2016). In addition, $\mathrm{NO}_{3}{ }^{-}$ions easily migrate in water and are subject to sorption to a small extent (Parzych 2011; Parzych et al. 2018a, b).

Iron and manganese in groundwater outflows are quite common, sometimes in high concentrations, and their presence is associated with the weathering of igneous and sedimentary rocks. The redox and $\mathrm{pH}$ conditions are the main factor determining their migration potential (Osadowski and Strzelczak 2009). In the studied area, there is the accumulation of organic matter in the form of peat (Jonczak and Parzych 2016; Parzych and Jonczak 2018), which 
Table 2 Results of principal component analysis (PCA) of macroand trace elements concentrations in thalli of Pellia endiviifolia

\begin{tabular}{lll}
\hline Elements & FC 1 & FC 2 \\
\hline $\mathrm{N}$ & -0.43 & $\mathbf{0 . 7 1}$ \\
$\mathrm{P}$ & $\mathbf{0 . 8 6}$ & $-0,31$ \\
$\mathrm{~K}$ & $\mathbf{0 . 8 0}$ & -0.01 \\
$\mathrm{Mg}$ & $\mathbf{0 . 7 9}$ & 0.15 \\
$\mathrm{Ca}$ & -0.60 & -0.43 \\
$\mathrm{Zn}$ & 0.23 & $-\mathbf{0 . 7 1}$ \\
$\mathrm{Fe}$ & -0.24 & -0.00 \\
$\mathrm{Cu}$ & -0.46 & -0.18 \\
$\mathrm{Ni}$ & 0.56 & 0.64 \\
$\mathrm{Mn}$ & $\mathbf{0 . 8 2}$ & -0.18 \\
$\mathrm{Al}$ & -0.68 & 0.49 \\
$\mathrm{Sr}$ & -0.60 & -0.67 \\
Eigen values & 4.66 & 2.48 \\
Explained variance $(\%)$ & 39 & 21 \\
& 60 & \\
\hline
\end{tabular}

Factor loading higher than 0.7 are in bold

Table 3 Average accumulation ( \pm standard deviation, SD) of components $^{\mathrm{a}}$ in thalli of Pellia endiviifolia

\begin{tabular}{lll}
\hline Elements & Average $\pm \mathrm{SD}$ & Participation $(\%)$ \\
\hline$\sum$ macro $\left(\mathrm{mmol}_{\mathrm{c}} / \mathrm{kg}\right)$ & $2407.3 \pm 183$ & 96.22 \\
$\% \mathrm{~N}$ in $\sum$ & 40.3 & \\
$\% \mathrm{P}$ in $\sum$ & 4.9 & \\
$\% \mathrm{~K}$ in $\sum$ & 38.1 & \\
$\% \mathrm{Mg}$ in $\sum$ & 5.0 & \\
$\% \mathrm{Ca}$ in $\sum$ & 12.1 & \\
$\sum \mathrm{trace}$ elements $\left(\mathrm{mmol}_{\mathrm{c}} / \mathrm{kg}\right)$ & $95.03 \pm 31$ \\
$\% \mathrm{Sr}$ in $\sum$ & 0.63 & \\
$\% \mathrm{Zn}$ in $\sum$ & 0.66 & \\
$\% \mathrm{Cu}$ in $\sum$ & 0.28 & \\
$\% \mathrm{Ni}$ in $\sum$ & 0.38 & \\
$\% \mathrm{Fe}$ in $\sum$ & 56.30 & \\
$\% \mathrm{Mn}$ in $\sum$ & 24.80 & 100 \\
$\% \mathrm{Al}$ in $\sum$ & 16.95 & 2502.28 \\
$\sum \mathrm{macro}+\sum$ trace elements &
\end{tabular}

${ }^{\mathrm{a}}$ Expressed as the sum of the components and their share in the total

is a potential source of $\mathrm{Fe}^{2 / 3+}$ and $\mathrm{Mn}^{2+}$ ion supply to stream waters. Low concentrations $\left(<0.01 \mathrm{mg} / \mathrm{dm}^{3}\right)$ of $\mathrm{Zn}^{2+}, \mathrm{Cu}^{2+}, \mathrm{Ni}^{2+}, \mathrm{Sr}^{2+}$ and $\mathrm{Al}^{3+}$ ions in stream waters unambiguously indicate the lack of influence of anthropogenic factors on the studied headwater niches.

\section{Concentration of Macro- and Trace Elements in Thalli of $\boldsymbol{P}$. endiviifolia}

Concentrations of macroelements in P. endiviifolia are in the range of average values resulting from the physiological needs of most plants (Markert 1992; Ostrowska and Porębska 2002). The obtained results indicate also that the studied thalli accumulated increased amounts of nickel $(>10 \mathrm{mg} / \mathrm{g})$ and large amounts of iron $(>1000 \mathrm{mg} / \mathrm{kg})$ and manganese $(>500 \mathrm{mg} / \mathrm{kg}$ ) (Kabata-Pendias and Pendias 1999). The physiological demand of plants for nickel is $0.1-5.0 \mathrm{mg} / \mathrm{kg}$, for manganese most often from 10 to $25 \mathrm{mg} / \mathrm{kg}$, and in the case of iron, it is usually below $375 \mathrm{mg} / \mathrm{kg}$. Samecka-Cymerman et al. (1997) indicate that thalli of Pellia epiphylla also accumulated large quantities of Fe (900-7500 $\left.\mathrm{mg} \mathrm{kg}^{-1}\right)$. For most species of plants, high concentrations of trace elements in their organs have negative impact on their growth and development, which is most often visible in morphological changes (SzatanikKloc 2004). Basile et al. (2017) suggest that in the case of Pellia neesiana, severe alterations were observed in chloroplasts from samples exposed in the most polluted $(\mathrm{Cd}, \mathrm{Pb})$ site of Sarno River in Italy. According to the Basile et al. (2012), at the ultrastructural level, sub-lethal concentrations of the heavy metals caused induced cell plasmolysis and alterations of the chloroplast arrangement in Lemna minor, Elodea Canadensis, and moss of Leptodictyum riparium. Esposito et al. (2012) showed that sublethal concentrations of cadmium caused the most severe modifications in the Leptodictype riparium, while other heavy metals caused only slight changes. The results of research by Satake et al. (1987) confirm strong accumulative properties of $P$. endiviifolia in relation with iron and manganese. In the thalli of the liverwort, they found from 44.7 to $2900 \mathrm{mg} / \mathrm{kg} \mathrm{Mn}$ and from 286 to $15,100 \mathrm{mg} / \mathrm{kg} \mathrm{Fe}$ at the concentration of $\mathrm{Mn}^{2+}<0.02 \mathrm{mg} / \mathrm{dm}^{3}$ and $\mathrm{Fe}^{2 / 3+}$ $<0.03 \mathrm{mg} / \mathrm{dm}^{3}$ in waters in Japan. Accumulation of high levels of iron and manganese in Pellia endivifolia confirms the potential use this species in the processes purification of waters contaminated with iron and manganese compounds. Both our and Satake et al. (1987) studies have been conducted under conditions of low $\mathrm{Fe}$ and $\mathrm{Mn}$ contents in water. It is difficult to predict changes in liverwort thallus and what amounts of these metals would accumulate in Pellia endiviifolia under their higher concentrations. This issue still requires further research to clarify accumulative properties of Pellia endiviifolia under various contamination conditions.

It was demonstrated that there were statistically significant differences in concentration of magnesium, iron, and copper in the thalli of the liverwort (Fig. 2). The amount of $\mathrm{Mg}, \mathrm{Fe}$, and $\mathrm{Cu}$ accumulated was determined by 
environmental conditions, and in the case of $\mathrm{N}, \mathrm{P}, \mathrm{K}, \mathrm{Ca}$, $\mathrm{Zn}, \mathrm{Ni}, \mathrm{Mn}, \mathrm{Al}$, and $\mathrm{Sr}$, the species-related features had stronger influence than environmental impacts.

Principal components analysis (PCA) showed that two factors played an important role in shaping chemical composition of $P$. endiviifolia (Table 2). The first one was created by macroelements ( $\mathrm{P}, \mathrm{K}$, and $\mathrm{Mg}$ ) necessary for proper functioning and $\mathrm{Mn}$ collected in excessive quantities from waters of an alkaline reaction (Table 1). These results are confirmed by Alloway (1995) oraz KabataPendias and Pendias (1999), who show that manganese compounds show the highest bioavailability for plants at pH 6 and 8. The second factor created by $\mathrm{N}$ and $\mathrm{Zn}$ indicates that in periods of maximum demand for nutrients, zinc is less available for plants in alkaline water (Table 1). According to Kabata-Pendias and Pendias (1999), the increase in zinc mobility is the most effective at $\mathrm{pH} 6$.

\section{Accumulation of Macro- and Trace Elements in Thalli of $P$. endiviifolia}

The uptake of nutrients by $P$. endiviifolia is to a large extent dependent on the species traits and physicochemical properties of stream water (Parzych et al. 2017). According to Ostrowska and Porębska (2002), the average values of the sum of components accumulated in plants usually range from 1200 to $2500 \mathrm{mmol}_{\mathrm{c}} / \mathrm{kg}$, and the share of micro-elements usually fluctuates within $1 \%$. P. endiviifolia accumulates slightly larger amounts of nutrients than other aquatic plants (Parzych and Cymer 2014; Parzych et al. 2015) and comparable to the amount of ingredients accumulated by herbaceous plants in peatlands (Parzych et al. 2018a, b).

The percentage of $\mathrm{Fe}$ and $\mathrm{Mn}$ in the sum of the components accumulated in the thalli of $P$. endiviifolia indicates a high demand for these micronutrients and shows the strong accumulation properties of this species in relation with iron and manganese. The results of the research presented in our work and data obtained by Satake et al. (1987) unequivocally indicate significant accumulation potential of the tested liverwort in relation to iron and manganese compounds that can be used in water treatment processes.

\section{Conclusions}

Analysis of accumulative properties of $P$. endiviifolia in relation with macro- and trace elements occurring in the forest headwater streams not affected significantly by anthropogenic factors, allowed to assess the nutrient needs and provided information on the accumulation capacities of $P$. endiviifolia. The thalli of the tested hepatic accumulated, on average, $2502.28 \mathrm{mmol}_{\mathrm{c}} / \mathrm{kg}$ of macro- and trace elements, with macronutrients accounting for $96.22 \%$ of this pool. The predominant share among trace elements was represented by $\mathrm{Fe}, \mathrm{Mn}$, and $\mathrm{Al}$ and the share of other elements was lower than $1 \%$. Differences statistically significant between stations indicate that the environmental conditions were decisive for the accumulated amount of $\mathrm{Mg}, \mathrm{Fe}$, and $\mathrm{Cu}$, while for $\mathrm{N}, \mathrm{P}, \mathrm{K}, \mathrm{Ca}, \mathrm{Zn}, \mathrm{Ni}, \mathrm{Mn}, \mathrm{Al}$, and $\mathrm{Sr}$ (no statistically significant differences), the influence of species characteristics was stronger than in case of environmental features. Accumulation in thalli of $P$. endiviifolia high concentrations of iron and manganese confirms the potential use this species in the processes purification of waters contaminated with iron and manganese compounds.

\section{Compliance with Ethical Standards}

Conflict of Interest The authors declare that they have no conflict of interest.

Open Access This article is distributed under the terms of the Creative Commons Attribution 4.0 International License (http://creative commons.org/licenses/by/4.0/), which permits unrestricted use, distribution, and reproduction in any medium, provided you give appropriate credit to the original author(s) and the source, provide a link to the Creative Commons license, and indicate if changes were made.

\section{References}

Alloway BJ (1995) Soil processes and the behavior of metals. In: Alloway BJ (ed) Heavy metals in soils, 2nd edn. Blackie, Glasgow, pp 7-28

Astel A, Czyżyk A, Parzych A (2014) Phytoremediation by soil toxicity reduction contaminated with heavy metals. Lab 4:6-12 (in Polish)

Basile A, Sorbo S, Conte B, Cobianchi R, Trinchella F, Capasso V, Carginale V (2012) Toxicity, accumulation, and removal of metals by three aquatic macrophytes. Int $\mathrm{J}$ Phytoremediation $14: 374-387$

Basile A, Sorbo S, Lentini M, Conte B, Esposito S (2017) Water pollution causes ultrastructural and functional damages in Pellia neesiana (Gottsche) Limpr. J Trace Elem Med Biol 43:80-86. https://doi.org/10.1016/j.jtemb.2016.11.014

Bukowska-Jania E (2003) The role of the glacial system in the calcium carbonate cycle in natural environment. Scientific works of the University of Silesia 2103, 247ss (in Polish)

Crandall-Stotler B, Stotler R (2000) Morphology and classification of the archantiophyta. In: Shaw AJ, Goffinet B (eds) Bryophyte biology. Cambridge University Press, Cambridge, pp 21-70

Esposito S, Sorbo S, Conte B, Basile A (2012) Effects of heavy metals on ultrastructure and hsp70s induction in the aquatic moss Leptodictyum riparium Hedw. Int $\mathrm{J}$ Phytoremediation 14(4):443-455

Grobelak A, Kacprzak M, Fijałkowski K (2010) Phytoremediation the underestimated potential of plants in cleaning up the environment. J Ecol Health 14(6):276-280 
He-Nygren X, Juslen A, Ahonen I, Glenny D, Piippo S (2006) Illuminating the evolutionary history of liverworts (Marchantiophyta)-towards a natural classification. Cladistics 22:1-31

Hughes JB, Shanks J, Vanderford M, Lauritzen J, Bhadra R (1997) Transformation of TNT by aquatic plants and plant tissue cultures. Environ Sci Technol 31:266-271

Jonczak J, Parzych A (2016) Properties of soil organic matter in soils of mid-forest spring niches in the Kamienna Creek valley (Middle Pomerania). Sylwan 160(2):135-143 (in Polish)

Jonczak J, Parzych A, Sobisz Z (2015) Decomposition of four tree species leaf litters in headwater riparian forest. Balt For 21(1):133-143

Jonczak J, Olejniczak M, Parzych A, Sobisz Z (2016) Dynamics, structure and chemistry of litterfall in headwater riparian forest in the area of Middle Pomerania. J Elem 21(2):383-394

Kabata-Pendias A, Pendias H (1999) Biogeochemistry of trace elements. Polish Scientific Publishing, Warsaw (in Polish)

Kirchenstein M, Baranowski D (2008) Annual precipitation and air temperature fluctuations and change tendencies in Słupsk. Dokumentacja Geograficzna 37:76-82 (in Polish)

Marecik R, Króliczak P, Cyplik P (2006) Phytoremediation-an alternative method for environmental cleanup. Biotechnology 3(74):88-97

Markert B (1992) Presence and significance of naturally occurring chemical elements of the periodic system in the plant organism and consequences for future investigations on inorganic environmental chemistry in ecosystems. Vegetatio 103:1-30

Mazurek M (2008) Headwater areas as a link connecting slope and river channel systems, the Parsęta River basin. Landf Anal 9:63-67 (in Polish)

Osadowski Z (2010) The influence of hydrological and hydrochemical conditions on vegetation cover diversity in spring areas of the postglacial landscape in the Pomerania region. Bogucki Scientific Publishing, Poznań (in Polish)

Osadowski Z, Strzelczak A (2009) Influence of iron and manganese on flora diversity of spring ecosystems in the middle part of the Pomerania. Fresenius Environ Bull 16(5):124-132

Ostrowska A (1999) ANE method and its application to the analysis of chemical composition of crops. Environ 16:99-112

Ostrowska A, Porębska G (2002) The chemical composition of the plant. Institute of Environmental Protection Press, Warszawa (in Polish)
Parzych A (2011) Contents of nitrogen and phosphorus compounds in ground waters of selected forest associations in the Słowiński National Park. Arch Environ Prot 37(4):95-105

Parzych A (2016) The chemical elements accumulation by organs of Sparganium erectum L. and their potential use in phytoremediation process. J Ecol Eng 17(1):89-100

Parzych A, Cymer M (2014) The content of macro- and microelements in the shoots of Glyceria maxima of the Słupia River. J Ecol Eng 15(4):29-36

Parzych A, Jonczak J (2018) Comparing nitrogen and phosphorus accumulation in vegetation associated with streams and peatbogs in mid-forest headwater ecosystem. J Elementol 23(2):459-469

Parzych A, Cymer M, Jonczak J, Szymczyk S (2015) The ability of leaves and rhizomes of aquatic plants to accumulate macro- and micronutrients. J Ecol Eng 16(3):198-205

Parzych A, Jonczak J, Sobisz Z (2016) Changes of water chemistry in mid-forest headwater streams in the valley of the Kamienna (Middle Pomerania). Sylwan 160(10):871-880 (in Polish)

Parzych A, Jonczak J, Sobisz Z (2017) Bioaccumulation of macronutrients in the herbaceous plants of mid-forest spring niches. Balt For 23(2):384-393

Parzych A, Jonczak J, Astel A (2018a) Spatiotemporal variability in headwater streams chemistry in young-glacial landscape of the southern Baltic Coastal Zone. Carpathian J Earth Environ 13(2):423-433

Parzych A, Jonczak J, Sobisz Z (2018b) Bioaccumulation of macroand micronutrients in herbaceous plants of headwater areas-a case study from northern Poland. J Elementol 23(1):231-245

Raskin I, Smith RD, Salt DE (1997) Phytoremediation of metals using plants to remove pollutants from the environment. Curr Opin Biotechnol 8:221-226

Samecka-Cymerman A, Marczonek A, Kempers AJ (1997) Bioindication of heavy metals in soil by liverworts. Arch Environ Contam Toxicol 33:162-171

Satake K, Nishikawa M, Shibata K (1987) Elemental composition of the sub-aquatic liverwort Pellia endiviifolia (Dicks.) Dum. in relation to heavy metal contamination. Hydrobiologia 148:131-136

Siwek M (2008) Biological ways of cleaning the environmentphytoremediation. Wiad Bot 52(1/2):23-28 (in Polish)

Szatanik-Kloc A (2004) Effect of $\mathrm{pH}$ and selected heavy metals in soil on their content in plants. Acta Agrophys 4(1):177-183 (in Polish) 